\title{
PEMANFAATAN KOMPOS KULIT KAKAO UNTUK MENGOPTIMALKAN PRODUKSI TANAMAN TERUNG (Solanum melongena L.)
}

\author{
Widia Yulianti ${ }^{1}$ dan Asrin Aburdin ${ }^{2}$ \\ Program Studi Teknologi Produksi Hortikultura Jurusan Budidaya Tanaman Pangan \\ Politeknik Pertanian Negeri Payakumbuh \\ Email: widiayulianti191208@gmail.com
}

\begin{abstract}
Eggplant (Solanum melongena L.) is a vegetable fruit favored by many because of its taste delicious and can be processed into a variety of food dishes. The eggplant has a significant position in Indonesia and consumption patterns, including commercial vegetable that has economic value is high enough, even eggplant is a significant export commodity. Eggplant community needs continue to increase from year to year along with population growth, but farmers have not been able to meet those needs. The fulfillment of these needs is done by optimizing production using compost eggplant cocoa skin. Nutrient content of compost made from the skin of cacao is $1.81 \% \mathrm{~N}, 26.61 \%$ organic C, $0.31 \% \mathrm{P} 2 \mathrm{O} 5,6.08 \% \mathrm{~K} 2 \mathrm{O}, 1.22 \% \mathrm{CaO}, 1.37 \% \mathrm{MgO}$, and $44,85 \mathrm{cmol} / \mathrm{kg}$ CEC. Independent Business Project objectives are to optimize crop production using compost eggplant with cocoa skin and be able to analyze the feasibility of cultivation of eggplant with market potential in the area Payakumbuh and Kota District Fifty.Independent Business project has been implemented in the field trials of State Agricultural Polytechnic Payakumbuh September to December 2015 with a land area of $206 \mathrm{~m} 2$. The technology used in the project is an independent business compost cocoa skin.Based on the results of the Project activities Independent Business (PUM) gained as much as $359 \mathrm{~kg}$ of eggplant production and a profit of USD 292670 for an area of $206 \mathrm{~m} 2, \mathrm{RC}$ ratio $1.36,36 \%$ profitability, BEP Rp 2,236/ kg, BEP results of $259 / \mathrm{Kg}$ and $B E P 151 \mathrm{~m} 2$ of land and the effort is worth the effort. It is therefore recommended to use composting technology for the cultivation of cocoa skin eggplant.
\end{abstract}

Keywords: Eggplant, cocoa bark compost

\section{INTISARI}

Terung (Solanum melongena L.) merupakan sayuran buah yang banyak digemari oleh berbagai kalangan karena cita rasanya yang enak dan bisa diolah menjadi berbagai hidangan makanan. Terung mempunyai peranan cukup penting dalam pola konsumsi masyarakat Indonesia dan termasuk sayuran komersial yang mempunyai nilai ekonomi cukup tinggi, bahkan terung merupakan komoditas ekspor yang cukup berarti. Kebutuhan masyarakat akan terung terus meningkat dari tahun ke tahun seiring dengan pertumbuhan penduduk, tetapi petani belum dapat memenuhi kebutuhan terhadap terung tersebut. Pemenuhan kebutuhan tersebut dilakukan dengan mengoptimalkan produksi terung menggunakan kompos kulit kakao. Tujuan Proyek Usaha Mandiri adalah mengoptimalkan produksi tanaman terung dengan menggunakan kompos kulit kakao dan dapat menganalisa kelayakan usaha budidaya tanaman terung. Proyek Usaha Mandiri ini telah dilaksanakan di lahan percobaan Politeknik Pertanian Negeri Payakumbuh pada bulan September sampai bulan Desember 2015 dengan luas lahan $206 \mathrm{~m}^{2}$. Teknologi dalam proyek usaha mandiri ini adalah kompos kulit kakao. Berdasarkan hasil kegiatan Proyek Usaha Mandiri (PUM) didapatkan produksi terung sebanyak $359 \mathrm{~kg}$ dan mendapatkan keuntungan sebesar $R p 292.670$ untuk luasan $206 \mathrm{~m}^{2}$, R.C ratio 1,36, profitabilitas 36\%, BEP harga $R p$ 2.236/Kg, BEP hasil 259/Kg dan BEP lahan $151 \mathrm{~m}^{2}$ dan usaha ini layak untuk diusahakan. Oleh sebab itu disarankan menggunakan teknologi kompos kulit kakao untuk budidaya tanaman terung.

Kata kunci: Terung, kompos kulit kakao

\footnotetext{
${ }^{1}$ Mahasiswa Program Studi Budidaya Tanaman Hortikuktura

${ }^{2}$ Staf Pengajar Program Studi Budidaya Tanaman Hortikultura
} 


\section{PENDAHULUAN}

Terung diduga berasal dari benua Asia, terutama India dan Birma. Beberapa petunjuk menyatakan bahwa tanaman terung banyak tumbuh di Cina, dari daerah ini kemudian dibawa ke Spanyol dan disebarkan ke negaranegara lain di Eropa, Afrika, Amerika Selatan, Malaysia dan Indonesia (Hastuti, 2007).

Terung merupakan salah satu jenis tanaman sayuran buah, dan banyak dimanfaatkan sebagai bahan makanan. Tanaman terung adalah tanaman asli daerah tropis yang cukup dikenal di Indonesia. Sayuran buah ini banyak digemari oleh berbagai kalangan karena cita rasanya yang enak dan bisa diolah menjadi berbagai hidangan makanan, seperti sayur lodeh, opor dan terung asinan.

Terung mempunyai peranan cukup penting dalam pola konsumsi masyarakat Indonesia. Buah terung termasuk sayuran yang mempunyai nilai ekonomi cukup tinggi. Terung merupakan komoditas ekspor yang cukup berarti. Pada tahun 1997 seorang pakar hortikultura Bob Sadino lewat perusahaanya PT Kem Farm berhasil mengekspor terung ke Jepang sebanyak 2.500 ton. Padahal prospek pasarnya diperkirakan 40.000 ton terung mentah setahun. Jadi bisa dikatakan usaha tani terung memiliki prospek yang cukup baik (Haryoto, 2009).

Petani saat ini cenderung memilih menggunakan pupuk kimia daripada menggunakan komposdalam budidaya tanaman terung. Hal ini karena kandungan hara di dalam pupuk kimia lebih tinggi sehingga pengaruhnya pada tanaman lebih cepat terlihat, sedangkan kompos pengaruhnya tidak terlihat dengan cepat. Kondisi ini mendorong petani menggunakan pupuk kimia dengan dosis berlebihan diluar dosis anjuran. Penggunaan pupuk kimia secara berlelbihan dan diluar dosis yang dianjurkan, megakibatkan terjadinya perubahan pada sifat fisik, kimia dan Biologi tanah. Kandungan bahan organik tanah berkurang, kesuburan tanah menurun, $\mathrm{pH}$ tanah tidak netral lagi, tanah cenderung keras dan susuah untuk mengikat air, sehingga hasil panen tanaman terung terus menurun. Salah satu cara untuk mengembalikan kondisi kesuburan tanah seperti semula adalah dengan menambahkan pupuk organik ke tanah pertanian dan mengurangi penggunaan pupuk kimia (Isroi, 2007). Pupuk organik adlah pupuk yang berasala dari sisa pelapukan bahan bahan organik sepertani pelapukan tanaman, dan kotoran hewan. Pupuk organik ada yang padat dan cair. Salah satu pupuk organik yang bisa digunakan yaitu kompos limbah kulit kakao dan kotoran ayam.

Kandungan hara mineral kulit buah kakao cukup tinggi, khususnya hara Kalium dan Nitrogen. Dilaporkan bahwa $61 \%$ dari total nutrien buah kakao disimpan di dalam kulit buah. Penelitian yang dilakukan oleh Goenadi et.al (2000) cit. Isroi (2007), menemukan bahwa kandungan hara kompos yang dibuat dari kulit buah kakao adalah $1,81 \% \mathrm{~N}, 26,61 \%$ C-organik, 0,31\% P2O5, 6,08\% K2O, 1,22\% $\mathrm{CaO}, 1,37 \% \mathrm{MgO}$, dan $44,85 \mathrm{cmol} / \mathrm{kg}$ KTK. Aplikasi kompos kulit buah kakao dapat meningkatkan produksi hingga 19,48\%.

Berdasarkan hal tersebut dilakukan Proyek Usaha Mandiri dengan judul "Pemanfaatan Kompos Kulit Kakao untuk Mengoptimalkan Produksi Tanaman Terung (Solanum melongena L.)".

Tujuan dari Proyek Usaha Mandiri (PUM) ini adalah sebagai berikut:

1. Mengoptimalkan produksi tanaman terung dengan menggunakan kompos kulit kakao.

2. Menganalisis kelayakan usaha budidaya tanaman terung

\section{METODE PELAKSANAAN}

\section{Waktu dan Tempat}

Proyek Usaha Mandiri ini telah dilakukan selama 4 bulan yang berlangsung dari bulan September sampai bulan Desember 2015. Proyek Usaha Mandiri ini dilakukan di lahan percobaan Politeknik Pertanian Negeri Payakumbuh di Kecamatan Harau Kabupaten Lima Puluh Kota dengan ketinggian tempat \pm 500 meter di atas permukaan laut.

\section{Alat dan Bahan \\ Bahan yang digunakan pada proyek usaha mandiri ini adalah: benih terung, kotoran ayam, kulit kakao, EM-4, gula pasir, karung, Urea, tali rafia, plastik hitam, pisau cutter, ajir, pupuk kandang, plastik bumbungan, kapur, Curacron, Dithane M-45, NPK Mutiara, curater dan NPK Grower. Sedangkan alat yang digunakan adalah: cangkul, kored, meterán, gembor, ember, parang dan knapsack sprayer.}




\section{Teknis Pelaksanaan}

\section{Proses Pembuatan Kompos Kulit Kakao}

Adapun proses pembuatan kompos kulit kakao dan kotoran ayam yaitu:

Kulit kakao sebanyak $250 \mathrm{~kg}$ dicacah untuk memperkecil ukuran bahan yang dapat dilakukan menggunakan parang. EM-4 $500 \mathrm{ml}$ dan gula 200 gram di larutkan ke dalam 60 liter air. Kotoran ayam sebanyak $250 \mathrm{~kg}$ dan kulit kakao dicampur hingga merata. Disiramkan larutan EM-4 secara perlahan-lahan ke dalam adonan hingga merata, sampai kandungan air adonan mencapai $30 \%$. Adonan digundukkan di atas ubin yang kering dengan ketinggian $1 \mathrm{~m}$, kemudian ditutup plastik hitam. Suhu adonan dipertahankan $40-50{ }^{\circ} \mathrm{C}$, sekali seminggu suhu diamati dan dilakukan pembalikan gundukan. Inkubasi dilakukan selama 1 bulan, dengan ciri kompos yang matang yaitu suhunya $25-30{ }^{\circ} \mathrm{C}$, berbau tanah dan warnanya coklat kehitamhitaman.

\section{Pesemaian}

Benih yang digunakan adalah benih bersertifikat yang dibeli ditoko pertanian dengan jenis terung ungu varietas Lezata F1, benih tanaman terung disemai langsung pada media bumbungan (plastik bumbungan). Media untuk penyemaian benih adalah pupuk kandang sapi dan tanah dengan perbandingan 1:1, penyemaian dilakukan di tempat yang ternaungi. Benih yang ditanam untuk 1 media bumbungan adalah 1 buah, kemudian benih yang sudah ditanami disiram supaya tidak kering. Setelah 3 hari benih berkecambah, bibit yang telah berumur 35 hari (berdaun 4-5 helai) bibit dipindahkan ke lapangan.

\section{Persiapan Lahan}

Lahan yang digunakan untuk budidaya tanaman terung sudah terbentuk bedengan, maka langsung dilakukan penggemburan tanah. Tanah digemburkan dengan menggunakan cangkul. Pada saat mencangkul tanah, semua kotoran seperti batu-batu, bekas-bekas polybag dan sisa-sisa tanaman dibuang. Setelah itu dilakukan pengapuran dengan menebarkan kapur sebanyak $50 \mathrm{~kg}$ secara merata di atas bedengan dan diaduk dengan tanah permukaan bedengan.

\section{Pemberian Kompos Kulit Kakao}

Pemberian kompos kulit kakao dilakukan 1 minggu sebelum tanam dengan dosis $1,1 \mathrm{~kg} / \mathrm{lubang}$ tanam. Lubang tanam dibuat dengan jarak $50 \times 70 \mathrm{~cm}$, dengan jumlah bedengan 2 baris didapatkan 310 lubang tanam dengan total kompos yang digunakan sebanyak $341 \mathrm{~kg}$.

\section{Penanaman}

Bibit terung yang ditanam di lahan merupakan bibit yang telah mempunyai 4-5 helai daun dan berumur 35 hari. Bibit maupun lubang tanam yang disiapkan dalam keadaan lembab sebelum penanaman. Bibit ditanam 1 per lubang tanam.

\section{Pemeliharaan}

Kegiatan pokok yang dilakukan dalam pemeliharaan tanaman terung adalah:

a. Penyiraman

Penyiraman dilakukan pada sore hari menggunakan gembor. Penyiraman disesuaikan dengan kondisi cuaca.

b. Penyulaman

Penyulaman dilakukan terhadap tanaman yang pertumbuhannya tidak normal, terserang hama penyakit dan mati. Penyulaman dilakukan sampai tanaman berumur 15 hari setelah tanam c. Pemupukan

Pemupukan dilakukan sebanyak empat kali. Pemupukan dilakukan saat tanaman berumur dua minggu setelah tanam dengan menggunakan pupuk NPK mutiara (16:16:16) sebanyak $2 \mathrm{~kg}$, setelah itu saat tanaman berumur satu bulan dipupuk dengan pupuk Urea sebanyak $2 \mathrm{~kg}$ dan tiga minggu setelah itu dilakukan pemupukan dengan NPK grower (15:9:20) sebanyak $2 \mathrm{~kg}$, dilanjutkan tiga minggu kemudian menggunakan pupuk NPK grower $2 \mathrm{~kg}$.

d. Pemasangan Ajir

Pemasangan ajir dilakukan setelah tanaman berumur 3 minggu, penancapan ajir berjarak $7 \mathrm{~cm}$ dari pangkal batang dan diusahakan ajir tidak melukai akar tanaman.

e. Penyiangan

Gulma yang tumbuh di aluran draenase dikendalikan secara mekanik ayitu, dengan membersihkan gulma dengan menggunakan cangkul, sedangkan yang tumbuh diatas bedengan dicabut dengan tangan dan dibantu dengan menggunakan kored.

f. Pemangkasan

Pemangkasan dilakukan dengan memotong tunas air, daun yang tua, buah yang terkena hama dan penyakit. Pemangkasan dilakukan dari umur 3 minggu setelah tanam sampai 1 minggu terakhir panen.

g. Pengendalian Hama dan Penyakit

Pengendalian hama dan penyakit yang dilakukan secara manual dan kimia. Hama yang menyerang tanaman berupa kumbang daun 
(Epilachna spp), belalang (Valanga nigricornis), ulat tanah (Agrotis ipsilon Hufn), Lalat Buah (Bactrocera $s p$ ) dan semut. Pada kondisi serangan hama masih dibawah ambang batas ekonomi, pengendalian dilakukan secara manual. Pada kondisi serangan semakin banyak maka dilakukan pengendalian secara kimia dengan insektisida Curacron, dosisnya $1 \mathrm{ml} /$ liter serta digunakan Curater untuk mengendalikan semut dengan dosis 0,80 gram/tanaman. Tanaman juga terserang penyakit busuk buah dan layu bakteri. Penyakit ini dikendalikan dengan fungisida Dithane M45, dosisnya 2 gram /1 liter.

\section{Panen dan Pasca Panen}

Panen pertama tanaman terung dilakukan pada umur 50 hari setelah tanam. Kriteria panennya yaitu ukuran buah sudah besar, berwarna ungu, tidak keras dan belum terbentuk biji. Cara panen buah terung adalah di petik bersama tangkainya dengan alat bantu pisau cutter. Panen buah berikutnya dilakukan setiap 4 hari sekali.

Penanganan pasca panen buah terung meliputi kegiatan sebagai berikut:

a. Pewadahan Sementara

Buah terung hasil petikan dilapangan langsung ditampung dalam ember dan dikumpulkan dalam satu tempat yang memadai. b.

ortasi dan Pengemasan

Sortasi buah terung sebelum dipasarkan dilakukan dengan memisahkan buah-buah yang busuk, abnormal, atau terkena serangan hama maupun penyakit. Buah terung yang sudah disortasi dimasukkan dalam karung dan disusun dengan teratur dan selanjutnya langsung di jual ke pedagang pengumpul atau dijual pada masyarakat disekitar Tanjung Pati.

\section{Pemasaran}

Pemasaran dilakukan mengecer ataupun menjual dalam skala besar ke distributor. Terung dijual dengan harga

\section{HASIL DAN PEMBAHASAN}

Teknologi yang digunakan pada proyek usaha mandiri ini yaitu kompos kulit kakao. Pengaruh teknologi yang digunakan dapat dilihat dari pertumbuhan tanaman yang optimal. Menurut Spillane dalam Sudirja, Solihin dan Rosniawaty (2005), mengemukakan bahwa kulit buah kakao dapat dimanfaatkan sebagai sumber unsur hara tanaman dalam bentuk kompos. Sebagai bahan organik kulit buah kakao mempunyai komposisi hara dan senyawa yang sangat potensial sebagai medium tumbuh tanaman.

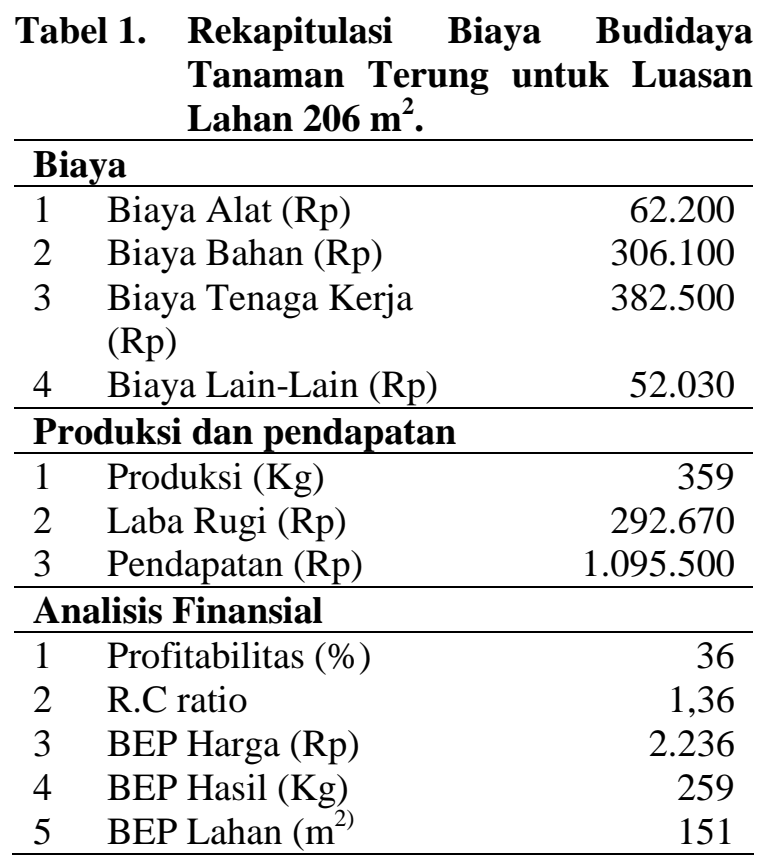

Produksi yang diperoleh dari proyek usaha mandiri tanaman terung dengan teknologi kompos kulit kakao cukup tinggi jika dibandingkan dengan produksi terung yang ada di Kabupaten Lima Puluh Kota pada tahun 2013, dimana pada perencanaan hasil yang diperoleh adalah $342,78 \mathrm{~kg}$ dengan luas lahan $300 \mathrm{~m}^{2}$ atau 11,426 ton/ha, sedangkan pada realisasinya diperoleh produksi $359 \mathrm{~kg}$ pada luas lahan $206 \mathrm{~m}^{2}$ atau 17,427 ton/ha.

Berdasarkan tabel 1, produksi yang diperoleh dalam proyek usaha mandiri dengan teknologi kompos kulit kakao adalah $359 \mathrm{~kg}$ atau 17,427 ton/ha dengan harga jual rata-rata Rp. $3.100 / \mathrm{kg}$. Pendapatan yang diperoleh Rp. 1.095.500, sedangkan biaya yang dikeluarkan Rp. 802.830, sehingga proyek usaha mandiri mendapatkan keuntungan Rp. 292.670 dan R. C Ratio yang didapat adalah 1,36 (proyek untung) serta profitabilitasnya $36 \%$ (proyek layak diusahakan).

Kukit kakao mengandung unsur hara yang cukup tinggi, seperti N,P dan K. Hal ini sesuai dengan pernyataan putri astria (2017) Aplikasi kombinasi $75 \%$ Urea $(163,05 \mathrm{~kg}$ ha-1) dan 25\% kompos kulit kakao (2,717 Mg ha-1) meningkatkan ketersediaan $\mathrm{N}(230,43 \%)$ dan menghasilkan ketersediaan $\mathrm{P}$ dan $\mathrm{K}$ tertinggi pada Inceptisols Tulungrejo Batu yaitu masingmasing $26,10 \mathrm{mg} \mathrm{kg}-1$, dan $0,95 \mathrm{cmol}$ 
kg-1. Sedangkan aplikasi 200\% kompos kulit kakao 21,739 Mg ha-1 memiliki nilai $\mathrm{C}$ organik dan $\mathrm{pH}$ tertinggi yaitu $2,17 \%$, dan 5,58 . Serapan $\mathrm{N}$ tanaman sawi tertinggi dihasilkan pada aplikasi $100 \%$ Urea $(217,40 \mathrm{~kg}$ ha-1) yaitu 16,44 mg tanaman-1. Aplikasi 75\% Urea dan 25\% kompos kulit kakao menghasilkan serapan $\mathrm{P}$, dan $\mathrm{K}$ tanaman tertinggi, masing-masing 3,08 dan 6,39 mg tanaman-1 dan menghasilkan luas daun 635,46 cm2tanaman-1, berat segar 48,57 g tanaman-1 tertinggi dan berat kering tanaman sawi 2,35 g tanaman-1 yang tidak berbeda nyata dengan aplikasi $100 \%$ urea.

Kompos kulit kakao da[at memperbaiki sifat fisik, kimia dan biologi tanah. $\mathrm{pH}$ tanah cenderung menjadi netral dengan pemberian kompos kulit kakao. Tanah cenderung menjadi gembur, sehingga dapat mengikat air dengan lebih baik. Air yang sudah tersedia dan terikat baik oleh tanah, dapat diserap oleh akar tanaman terung dan menyebabkan proses metabolisme tanaman berjalan dengan baik. Sehingga dapat meningkatkan produksi tanaman terung. Hal ini sesuai dengan pernyataan Rija Sdujirja (2005)yang menyatakan secara mandiri, kompos bioaktif kulit buah kakao memberikan pengaruh nyata terhadap perbaikan $\mathrm{pH}$ tanah dan C-organik.

Kendala yang terjadi saat awal tanam diantaranya curah hujan yang sangat sedikit sehingga tanaman sering layu walaupun disiram setiap hari. Menurut Rahman (2015), tumbuhan merespon kekurangan air dengan mengurangi laju transpirasi untuk penghematan air. Terjadinya kekurangan air pada daun akan menyebabkan sel-sel penjaga kehilangan turgornya, suatu mekanisme kontrol tunggal yang memperlambat transpirasi dengan cara menutup stomata. Kekurangan air juga merangsang peningkatan sintesis dan pembebasan asam absisat dari sel-sel mesofil daun. Hormon ini membantu mempertahankan stomata tetap tertutup dengan cara bekerja pada membran sel penjaga. Daun juga berespon terhadap kekurangan air dengan cara lain.

Selain itu terdapat kabut asap yang sangat pekat sehingga kurangnya sinar matahari yang dibutuhkan tanaman untuk proses fotosintesis. Menurut Catur dalam Anonim (2015), setiap tanaman membutuhkan sinar matahari yang cukup, sebab hal tersebut merupakan syarat agar tumbuhan dapat berfotosintesis dengan baik. Namun, dengan pekatnya kabut asap maka sinar matahari yang bisa diperoleh tanaman tidak dapat maksimal,
Pengendalian hama dan penyakit juga dilakukan yaitu dengan cara manual dan kimia. Secara manual yaitu mengambil hama yang menyerang dan memusnahkannya. Hama yang banyak menyerang yaitu kumbang daun (Epilachna spp), belalang (Valanga nigricornis), ulat tanah (Agrotis ipsilon Hufn), Lalat Buah (Bactrocera $s p$ ) dan semut. Setelah serangan hama semakin banyak maka dilakukan pengendalian secara kimia yaitu dengan penyemprotan Curacron dan Dithane M-45 serta pemakaian Curater untuk mengendalikan semut.

\section{KESIMPULAN DAN SARAN}

Dari pelaksanaan proyek usaha mandiri budidaya tanaman terung ini dapat disimpulkan bahwa:

1. Pemanfaatan kompos kulit kakao dapat mengoptimalkan produksi tanaman terung.

2. Pemanfaatan kompos kulit kakao pada budidaya tanaman terung mampu menghasilkan produksi sebanyak $359 \mathrm{~kg}$ dengan luas lahan $206 \mathrm{~m}^{2}$ dan mendapatkan keuntungan Rp. 292.670, R. C Ratio 36\% dan Profitabilitas 1,36\% sehingga usaha ini layak untuk diusahakan.

Berdasarkan kesimpulan diatas, pada budidaya terung disarankan menggunakan kompos kulit kakao karena mampu mengoptimalkan produksi tanaman terung.

\section{DAFTAR PUSTAKA}

Ali. 2015. Pengertian dan manfaat pupuk kompos. http://www.pengertianpakar. com/2015/01/pengertian-dan-manfaatpupuk-kompos.html. Diunduh 9 Februari 2016.

Anonim. 2014. Panduan praktis budidaya terung.http://alamtani.com/budidayaterung.html. Diunduh 10 Mei 2015.

Anonim. 2015. Kabut asap berpotensi turunkan produktivitas tanaman. http://www.medanbisnisdaily.com. Diunduh 9 Februari 2016.

Haryoto. 2009. Bertanam terung dalam pot. Kanisius, Yogyakarta. 48 hal.

Hastuti, D. W. S. 2007. Terung tinjauan langsung ke beberapa pasar di kota Bogor. repository.usu.ac.id/bitstream/ 123456789/832/1/07002689.pdf. Diunduh 10 Maret 2015 
Isroi.2007. Pengomposan limbah kakao. http://isroi.files.wordpress.com. Diunduh 30 April 2015.

Rahman. 2015. Respon tumbuhan terhadap cekaman lingkungan. http:// biomedi siana.com/respon-tumbuhan-terhadapcekaman-lingkungan. Diunduh 9 Februari 2016.

Sudirja, R., Solihin, M., A., Rosniawaty, S. 2005. Pengaruh kompos kulit buah kakao dan kascing terhadap perbaikan beberapa sifat kimia fluventic eutrudepts.

http://pengaruh_kompos_kulit_buah_ka kao_dan_kascing.pdf. Diunduh 23 Januari 2016.

Suwarto. 2002. Uji penngemburan lingkungan perakara terhadap pertumbuhan dan hasil kacang tanah di tanah latosol. http//:www.jurnal.fp.ac .id/uji penggemburan lingkungan perakaran. Diunduh 9 Februari 2016.

Toro. 2011. Pemupukan berimbang. http:// blog.uad.ac.id/toro/tag/pemupukan/.

Diunduh 9 Februari 2016. 